\title{
Új irányok a szakképzés és a felnőttképzés területén - különös tekintettel a raktározási ágazat aktuális kérdéseire
}

\author{
New Directions in Vocational and Adult Education - Especially with Regard \\ to Current Issues in the Storage Sector
}

\begin{abstract}
ABSZTRAKT
A negyedik ipari forradalom kihívásai az élet számos területén éreztetik hatásukat. Mindez alól a szakképzési és felnőttképzési rendszer sem jelent kivételt. Összhangban a változásokkal, hazánkban rendszerszintü átalakitások és fejlesztések mennek végbe ezen a területen, megteremtve az alapjait a minőségi szakemberképzés biztositásának. Kiemelt relevanciával bíró kérdéskörnek véljük a raktározási ágazat vonatkozásában felmerülö kérdéseket, illetve azon lehetöségek feltérképezését, amelyek az új változásokkal összhangban megoldási lehetőségeket kínálnak a fokozott veszéllyel járó tevékenységek kapcsán is. A raktározási ágazat - és ezzel együtt a legtöbb nemzetgazdasági ágazat - egyik alapvető problémájával foglalkoztunk, amely nem más, mint a minőségi szakemberképzés. Úgy véljük, hogy a jelenlegi szakképzési és felnöttképzési rendszer középtávon mindenképpen elömozdítja a raktározási ágazatban jelenleg meglévő szakemberhiány kezelését. Egy kiragadott gyakorlati kérdés mögött szakpolitikai területek összekapcsolódását és egymásra épülését láthatjuk. Ezt igyekeztünk jelen tanulmányunkban megválaszolni és kontextusba helyezni.
\end{abstract}

Kulcsszavak: szakképzés, felnőttképzés, munkavédelem, egészséges munkakörnyezethez való jog, raktározási ágazat

\begin{abstract}
The challenges of the Fourth Industrial Revolution are having an impact in many areas of life. The vocational and adult education system is no exception. In line with the changes, system-level transformations and developments are taking place in Hungary in this field, creating the basis for ensuring quality professional training. We consider the issues related to the warehousing sector to be of special relevance, as well as the examination of the possibilities that, in accordance with the new changes, offer solutions to the high-risk activities as well.
\end{abstract}

Keywords: vocational training, adult training, occupational safety, the right to a healthy working environment, the storage sector

A munkaerőpiac radikális változáson megy keresztül, többek között a megállíthatatlan technikai fejlődésnek köszönhetően. A globális gazdasági válság leginkább

* Dr. Jakab Nóra, egyetemi tanár, Miskolci Egyetem Állam- és Jogtudományi Kar, Civilisztikai Tudományok Intézete, e-mail: nora.jakab@uni-miskolc.hu. Dr. Berényi Laura, PhD-hallgató, Deák Ferenc Állam- és Jogtudományi Doktori Iskola, e-mail: jogberi@uni-miskolc.hu. Dr. Ráczi Zsófia, PhD-hallgató, Deák Ferenc Államés Jogtudományi Doktori Iskola, e-mail: zsofiaraczi@gmail.com. 
a fiatal korosztály munkavállalási lehetőségeit érintette, érinti katasztrofálisan. Ma a fiatalok összesen 45 százalékának van munkája, kevesebbnek, mint 2007 decemberében, a válság kitörésekor. Ugyanakkor az időseknél éppen fordított a helyzet. Ezt támasztja alá például, hogy az amerikai nyugdíjasok 18 százaléka dolgozik, és azt is, hogy a nyugdíjasok foglalkoztatási rátája 2012-ben volt a legmagasabb 1965 óta. A jelenség - a demográfiai és egészségügyi okok mellett - ugyancsak a válság számlájára írható. A legtöbben ugyanis egyszerủen nem engedhetik meg maguknak, hogy ne dolgozzanak. Nem vonulnak nyugdíjba, ennek következtében pedig nem adják át sem a helyüket, sem a tudásukat a fiatalabb generációknak. Az 1997-től elindult nyugdíjkorhatár-emelés, amelynek következtében mind a nők, mind a férfiak esetében egységesen nőtt az öregségi nyugdíjazás korhatára, szintén erősíti ezt a jelenséget. A demográfiai okok közül a népesség elöregedését szükséges kiemelnünk, amelyet a termékenység csökkenése és a várható élettartam növekedése okoz. Az évszázad végére a várható élettartam a Földön az előzetes számítások szerint a jelenlegi 68 évröl 81 évre növekszik majd. Ennek következtében kialakulhat az úgynevezett „egyharmados” népesség: a népesség egyharmada - azaz minden harmadik ember - az időskorúak közé fog tartozni. Ezek a társadalmi-demográfiai folyamatok nyomon követhetőek a vállalatoknál is. A vállalatok korfája (a szervezetben dolgozók életkor és nem szerinti eloszlása) folyamatosan változik, követve a társadalmi változásokat. Az ötvenes években még jellemzően a 20-30 év közöttiek tették ki az alkalmazottak nagy részét - az optimális piramis modellben -, de ez napjainkra drasztikusan átalakult. A munkaerőpiac gerincét az $\mathrm{X}$, valamint a Baby Boom generációk alkotják, és csak őket követi az Y generáció. Kivételt ez alól csak az informatikai cégek képeznek, ahol többnyire az Y generációs munkavállalók a jellemzőek. ${ }^{1}$

Ez a helyzet a prognózisok szerint csak tovább fokozódik a jövőben: jóval kevesebb fiatal fog dolgozni a cégeknél, ezzel szemben magasabb lesz az idősebb korosztályok jelenléte. A munkaerőpiac radikális átalakuláson megy át: a munkaerőkereslet (kiemelten a fiatal, tehetséges munkavállalók iránt) várhatóan jelentősen megnő, míg a kínálat nagymértékben csökken, ami elöreláthatóan a munkáltatók közötti verseny fokozódásához vezet, átalakítva a munkaerőpiac kínálati oldalát. A munkáltatóknak fel kell készülni arra, hogy a munkavállalók egyre hosszabb időt kénytelenek a munkaerőpiacon és a munkahelyeken eltölteni. Ez problémát jelent a komoly fizikai és pszichikai megterhelést jelentő munkakörökben és munkahelyeken, mint amilyen a raktározás is. Jelen tanulmány egy kutatás ${ }^{2}$ eredményeinek egy részét foglalja röviden össze, amelynek során a vizsgálódás fókuszául a raktározási ágazat problémái, illetve az azokra való megoldási javaslatok kidolgozásra kerültek az elemzés középpontjába. A kutatásunk leginkább desk research jellegü volt, föként $\mathrm{KSH}$-adatok és statisztikák alapulvételével dolgoztunk.

A logisztika egyik legnagyobb kihívása egyértelműen a munkaerőhiány: az iparágban az összes üres munkahely száma 5 év alatt megnégyszereződött, így 3636

\footnotetext{
${ }^{1}$ KISSNÉ ANDRÁs Klára: Generációk, munkaerőpiac és a motiváció kérdései a 21. században. http://www.ohe.hu /hrmagazin/cikkek/generaciok-munkaeropiac-es-a-motivacio-kerdesei-a-21-szazadban (2021. 07. 01.).

${ }^{2}$ GINOP-5.3.5-18-2018-00081 projekt.
} 
üres álláshely volt 2018 szeptemberében. A technológiai fejlődés ugyanakkor nem áll le, sőt egyes kutatók szerint sebessége exponenciálisan nő ${ }^{3}$, így az a vállalat, amely nem lép időben, könnyen csődbe mehet. Ezért is értékelődött fel a különböző automatikus technológiák szerepe, illetve a raktáron belüli folyamatok újratervezése a raktárlogisztikában. A raktározás és a raktárak müködésének biztosítása mindenhol kulcskérdés, legyen szó akár gyártásról vagy kereskedelemről. Mindenhol a raktárak biztosítják a hátteret az egységek müködéséhez. Akár ágazati szinten vizsgáljuk a kérdést, akár egy egység raktármüködését vesszük alapul, megállapíthatók a fö működési elvek. Minden raktárban van beérkező és kiszállítani szükséges termék, áru vagy termény. Az élelmiszerraktárak, ezen belül is a frissáruraktárak működtetése az egyik legnagyobb kihívást jelentő raktározási tevékenység, mivel ezekben a raktárakban többnyire rövid szavatosságú termékeket raktároznak. Itt kulcsfontosságú a rakodást végző személyek állandó biztosítása. Akkor alakulhat ki válsághelyzet egy raktári müködésben, ha az adott müszakban vagy müszakokban nincs megfelelő számú vagy megfelelő képességgel rendelkező munkavállaló az áruk fel- vagy lerakására. Ez az oka annak, hogy manapság egy targoncavezetői engedéllyel rendelkező munkavállaló nagyon nagy értéket képvisel a munkaerőpiacon, ágazattól függetlenül. Magyarországon már évek óta nem elegendő, amennyiben a munkavállaló rendelkezik a targonca- vagy rakodógép vezetéséhez szükséges vezetői okmánnyal. Hazánkban ezt a tevékenységet szakmaként kezelik, és a targoncavezetői engedéllyel rendelkező munkavállalók csak megfelelő OKJ-vizsgával, valamint az adott telephelyre szóló megbízással vezethetnek targoncát. Éppen ezért tanulmányunk megírását egy gyakorlati oldalról érkező kérdés megválaszolása ihlette: mely esetekben lenne lehetőség a meghatározott végzettséget megkövetelö, rendkívül szigorú elöírások esetleges lazítására? Továbbá azt a kérdést is érdemes körbejárni, hogy a megfelelő gyakorlati idő kiválthatná-e az OKJ-s tanfolyam elvégzését.

Meggyőződésünk, hogy a már említett rohamos mértékủ technológiai fejlődés, valamint a megváltozott társadalmi és gazdasági igényekhez igazodó munkaerőpiaci elvárások szüntelen formálódása okán elengedhetetlenné vált a szakképzés és felnőttképzés megújítása, éppen ezért kihívás a gyakorlati kérdés érintettek oldalán történő megnyugtató rendezése. Kétséget kizáróan kijelenthetjük, hogy a gazdasági növekedés csak abban az esetben biztosítható hosszú távon, ha az innovatív technikák, eljárások - többek között az automatizációban rejlő lehetőségek - hatékonyságnövekedést eredményeznek, és ehhez a munkaerőpiac rendelkezésére áll a megfelelő számú és megfelelő képesítéssel rendelkező szakember. Ezen elképzelés hatékony és fenntartható megvalósításának kulcsa - összhangban az uniós célkitűzésekkel ${ }^{4}$ - a gazdaság mindenkori igényeihez jobban alkalmazkodó

${ }^{3}$ Lásd erröl: KURzWEIL, Ray: A szingularitás küszöbén. Ad Astra, Budapest, 2013.

${ }^{4}$ Lásd erről: A Bizottság közleménye a Tanácsnak az ifjúságot érintő európai szakpolitikákról. Napirenden az európai fiatalokat foglalkoztató kérdések: Az Európai ifjúsági paktum végrehajtása és az állampolgári szerepvállalás ösztönzése [SEC(2005)693]. A Tanács nyilatkozata a tevékeny idöskor és a nemzedékek közötti szolidaritás európai évéről: A következő lépések. 2012. december 7. Lásd még az alábbiakat: az aktív idősödés és a nemzedékek közötti szolidaritás európai évéről (2012) szóló 2011. szeptember 14-i 2011/940/EU európai parlamenti és tanácsi határozat, a foglalkoztatás és a munkavégzés során alkalmazott egyenlő bánás- 
szakképzési és felnőttképzési rendszer lehet. Ennek okán a gyakorlati oldalról érkező kérdés körbejárása érdekében megvizsgáltuk a szakképzés jelenlegi reformját, az abból adódó lehetőségeket és a munkavégzéssel járó - témánk szempontjából releváns - kockázatok jogi hátterét is. Mindenekelőtt azonban érdemes kiemelni, hogy a raktározási ágazat milyen volument képvisel a nemzetgazdasági ágazatban.

\section{A raktározási ágazat jelentősége a nemzetgazdaságban}

2016. december 31-én a nemzetgazdaság egészében 1,8 millió, ezen belül a szállítás, raktározás nemzetgazdasági ágban 37,4 ezer gazdasági szervezetet tartottunk nyilván, aránya 2,0\% volt, ez utóbbi gyakorlatilag nem változott 2014 óta. A szállítás, raktározás nemzetgazdasági ágban 2016 év végén regisztrált gazdasági szervezetek kétharmada 1-4 főt foglalkoztató mikrovállalkozás volt, ${ }^{5}$ arányuk egy év alatt 8 százalékponttal csökkent. 2016-ban a nemzetgazdasági ágba sorolt szállítási, szállítást kiegészítő, tárolási, raktározási, postai tevékenységet végző szervezetek az

mód általános kereteinek létrehozásáról szóló, 2000. november 27-i 2000/78/EK tanácsi irányelv, az Európai Unió alapjogi chartájára, különösen annak az idősek jogairól szóló 25. cikke, a Bizottságnak a tevékeny és egészséges időskor témájára vonatkozó innovációval kapcsolatos, 2015. március 9-10-én megtartott európai csúcstalálkozóról szóló végleges jelentése, a Bizottság 2015. február 23-i, „Az ezüst gazdaság növelése” című háttérdokumentuma, a tevékeny időskor és a nemzedékek közötti szolidaritás 2012-es európai évének végrehajtásáról, eredményeiről és átfogó értékeléséről szóló, 2014. szeptember 15-i bizottsági jelentésre [COM(2014)0562], a Bizottság „2015. évi jelentés a népesség idősödéséről: Gazdasági és költségvetési prognózisok az EU 28 tagállamára vonatkozóan (2013-2060)” című jelentésére (Európai Gazdaság 3|2015), az etnikai származásra való tekintet nélküli egyenlő bánásmód elvének alkalmazásáról szóló, 2000. június 29-i 2000/43/EK tanácsi irányelv (faji egyenlőségi irányelv) és a foglalkoztatás és a munkavégzés során alkalmazott egyenlő bánásmód általános kereteinek létrehozásáról szóló, 2000. november 27-i 2000/78/EK tanácsi irányelv (foglalkoztatási egyenlőségi irányelv) alkalmazásáról szóló, 2014. január 17-i bizottsági közös jelentésre [COM(2014)0002], a Bizottság „Szociális beruházás a növekedés és a kohézió érdekében, többek között a 2014-2020-as időszakra szóló Európai Szociális Alapon keresztül” című 2013. február 20-i közleményére [COM(2013)0083], a szociális beruházási csomag 2014. évi végrehajtására vonatkozó bizottsági politikai ütemterv, „A megfelelő, biztonságos és fenntartható európai nyugdíjak menetrendje” című, 2012. február 16-i bizottsági fehér könyv [COM(2012)0055], az aktív és egészséges időskor témájával kapcsolatos európai innovációs partnerség stratégiai végrehajtási tervének előreviteléről szóló, 2012. február 29-i bizottsági közlemény [COM(2012)0083], „A tevékeny időskor és a nemzedékek közötti szolidaritás európai éve (2012): A következő lépések” című 2012. december 7-i tanácsi nyilatkozat, a „Megfelelő szociális védelem az idősödő társadalmakban a tartós ápolásra-gondozásra szorulás kivédése érdekében" című 2014. október 10-i, a szociális védelemmel foglalkozó bizottság és a Bizottság által közösen készített jelentés, az Európai Alapítvány az Élet- és Munkakörülmények Javításáért (Eurofound) 2014. október 31-i „Az egészségügyhöz való hozzáférés válság idején" című jelentése, az időskorral foglalkozó ENSZ-munkacsoport jelenlegi munkájára, melynek célja egy az idős emberek jogainak védelmére irányuló egyezmény létrehozása, az Eurofound „Munkavégzési preferenciák 50 után” címmel megjelent megállapításaira (2014), az Eurofound „Fenntartható munka: A jobb és hosszabb munkával töltött élet felé” címmel megjelent fókuszdokumentumára (2014. december), az Európai Parlament Kutatószolgálata által 2015 márciusában készített „Az aktív időskor és a nemzedékek közötti szolidaritás európai éve (2012)” című mélységi elemzésre, „A tevékeny időskor és a nemzedékek közötti szolidaritás európai éve" című, az Ecorys által készített 2014. április 15-i végleges jelentés.

${ }^{5}$ Ez a kérdés különösen érdekes lehet a kkv-szektor szempontjából. Kutatásaink következő állomásán ezzel is kívánunk foglalkozni. 
előzetes éves adatok alapján folyó áron összesen 1956 milliárd forint bruttó hozzáadott értéket (alapáron) állítottak elő, ami 6,7\%-kal volt több az előző évinél. Ezzel a teljesítményükkel 6,5\%-kal járultak hozzá a teljes nemzetgazdaság bruttó hozzáadott értékének előállításához. 2016-ban a nemzetgazdasági beruházások 5139 milliárd forint folyó áron számított teljesítményértékének 13\%-át, 685 milliárd forintot realizáltak ebben az ágban. 2016-ban a teljes nemzetgazdaságon belül a szállítás, raktározás, a kapcsolódó kiegészítő, valamint a postai és futárpostai tevékenységet végző szervezeteknél a teljes munkaidőben foglalkoztatottak $7,1 \%$-os részaránya nem változott az egy évvel korábbihoz képest. ${ }^{6}$

A gazdasági szervezetek regiszterében 2016 végén a szállítás, raktározás ágba gazdálkodási forma szerint 14,5 ezer korlátolt felelősségủ társaságot tartottunk nyilván, a társas vállalkozások $81 \%$-át. Bár a társas vállalkozások több mint $17 \%$-át kitevő, 3,1 ezer nyilvántartott betéti társaság száma a jogi környezet változása miatt is évröl évre fokozatosan csökkent (2016-ban 8,7\%-kal), továbbra is jelentős gazdálkodási forma maradt. 2015-ben a szállítás, raktározás nemzetgazdasági ágban működő vállalkozások 82\%-a 1-4 föt foglalkoztató mikrovállalkozás volt.

2016-ban a szállítási ágazatok közül a raktározást, szállítást kiegészítö tevékenység ágazatba sorolt szervezetek beruházásainak részaránya volt a legnagyobb (62\%), ugyanakkor az előző évihez képest teljesítményértékük folyó áron 303 milliárd forinttal, volumenében - a szállítás, raktározás ágat is meghaladó mértékben - 43\%-kal csökkent 2015-höz képest. ${ }^{7}$

2016-ban a szállítási, raktározási ágban működő gazdasági szervezetek teljes munkaidőben közel 190 ezer főt foglalkoztattak, arányuk a nemzetgazdaságban változatlanul 7,1\% volt, számuk több mint 5400 fővel nőtt az előző évihez képest. A szállítás, raktározás ágba tartozó ágazatok közül az elmúlt évben a szárazföldi, csővezetékes szállítás ágazatban dolgozott a teljes munkaidős !innen hiányzik a mondat vége!

Az ágazatban tehát jelentős a gazdasági szervezetek aránya, a foglalkoztatottak száma, valamint a szervezetek, amelyek föleg mikrovállalkozások, bruttó hozzáadott értéke a nemzetgazdasághoz. A továbbiakban raktározási ágazat egyik fontos kérdését vizsgáljuk meg távolabbi fókuszból. Az ágazatban felmerülő kérdések ugyanis a szakképzés reformjához vezetnek bennünket, valamint annak európai és magyar kontextusához.

${ }^{6}$ Az ágazat nemzetgazdaságban betöltött szerepéről begyűjtött adatok a KSH kiadványából származnak. A szállítási ágazat helyzete, 2016, https://www.ksh.hu/docs/hun/xftp/idoszaki/jelszall/jelszall16.pdf (2021. 07. 01.). A 2016. december 31-i állapot szerint a nemzetgazdaság egészében a regisztrált vállalkozások száma - a 2015. évi visszaesést követően - csekély, 0,4\%-os mértékben bővült, számuk megközelítette az 1,7 milliót. Ahogy a korábbi években, úgy 2016-ban is a regisztrált gazdasági szervezeteken belül a vállalkozások súlya volt a meghatározó - nemzetgazdasági szinten $92 \%$, a szállítás, raktározás ágban pedig $99 \%$. A szállítás, raktározás ágban kisebb mértékben, de tovább folytatódott az évek óta tartó csökkenő tendencia, aminek következtében 2016 végére az összes vállalkozás száma 1,0\%-kal, 36,8 ezerre mérséklődött. Ezen belül a társas vállalkozások és az önálló vállalkozók 2015. december 31-i, még közel azonos, 50-50\%-os aránya egy év alatt (1,5 százalékponttal) eltolódott ez utóbbi gazdálkodási forma javára.

${ }^{7}$ Ennek oka, hogy az ágazaton belül a $88 \%$-os súlyú szárazföldi szállítást kiegészítő tevékenység szakágazatban egy év alatt a folyó áron számított beruházási teljesítményérték 306 milliárd forinttal csökkent. Ezt a visszaesést nem tudta ellensúlyozni az ágazaton belül kisebb részarányt képviselő rakománykezelés szakágazat $77 \%$-os (+1,8 milliárd forint), és a légi szállítást kiegészítő szolgáltatás $22 \%$-os (+2,2 milliárd forint) beruházási teljesítményértékének bővülése sem. 


\section{Szakképzés 4.0}

A szakképzés jelentőségét az európai szakpolitika is több dokumentumban hangsúlyozta. Az Európai Tanács kiemelte, hogy Európának az alábbi területeken kell cselekednie: „Foglalkoztatás: A demográfiai változások miatt a munkaképes korúak száma csökkenni fog. Jelenleg a munkaképes korú népességnek csak kétharmada áll alkalmazásban: ez az arány az Egyesült Államokban és Japánban $70 \%$ felett van. Különösen a nök és az idősek foglalkoztatási aránya alacsony. A fiatalokat keményen sújtotta a válság, körükben $21 \%$ a munkanélküliek aránya. Nagy a kockázata annak, hogy a munka világából kimaradók, illetve ahhoz csak lazán kapcsolódók teljesen elveszítik a munkaeröpiaccal fenntartott kapcsolatot.

Szakképzettség: Megközelítőleg 80 millióan csak gyenge vagy alapkészségekkel rendelkeznek, az élethosszig tartó tanulás pedig elsősorban a legképzettebbeket segíti. 2020-ig 16 millióval nő majd a felsőfokú képzettséget igénylö állások száma, az alacsony képesitéssel rendelkezőknek fenntartott állások száma pedig 12 millióval csökkenni fog. A hosszabb karrier érdekében életünk során előfordulhat, hogy új készségeket kell elsajátítanunk vagy kifejlesztenünk."

${ }^{8}$ Kulcsfontosságú szakpolitikai üzenetek a foglalkoztatási válsághelyzetek kezelésében az alábbiak: „A munka tisztességes és méltányos jövőjének biztosításához elengedhetetlen, hogy a szociális partnerek erősek legyenek, és hogy a szociális párbeszéd minden szinten hatékony legyen. A munka megváltozott világában a szociális partnereknek módot kell találniuk arra, hogy a gazdaságilag aktív, különféle foglalkoztatási formák keretében tevékenykedő polgárok mindegyike megfelelően képviselve legyen, és szempontjaik meghallgatásra találjanak a szociális párbeszéd során... A foglalkoztatás mintázatainak változása hatással van a munkáltatók és a munkavállalók közötti feladatmegosztásra: egyes esetekben - például a munkahelyi egészség és biztonság és a munkaidő tekintetében - a munkavállalóknak nagyobb felelősséget kell vállalniuk a munkakörülményeikért. A foglalkoztatási mintázatok változásaitól függetlenül mindenki számára tisztességes munkakörülményeket kell biztosítani... A kormányoknak megfelelö keretfeltételeket kell teremteniük az egész életen át tartó tanulásban és az iskolarendszeren túli oktatásban való részvételhez. A kormányoknak és az oktatási intézményeknek szorosan együtt kell müködniük a vállalkozásokkal és a szociális partnerekkel nemcsak azért, hogy az oktatás megfeleljen a munkaerőpiaci igényeknek, hanem azért is, hogy ellássa a tanulókat azokkal az általános készségekkel, amelyek ahhoz szükségesek, hogy a társadalomban teljes értékü szerepet töltsenek be, és hogy képesek legyenek a pályafutásuk során később újabb készségeket elsajátítani (azaz megtanuljanak tanulni)." A 2017 novemberében elfogadott, munka jövőjét érintő tanácsi következtetések (Council on the Future of Work: Making it e-Easy; 14954/17). „Az alacsony szintű készségekkel, tudással és kompetenciákkal rendelkező felnőttek számára - például azok számára, akik úgy kerültek ki az iskolarendszerü oktatás-képzésböl, hogy nem szereztek felső középfokú vagy azzal egyenértékü végzettséget, és az ifjúsági garancia keretében nem jogosultak támogatásra - kínáljanak lehetőséget olyan kompetenciafejlesztési pályák igénybevételéhez, amelyek egyéni igényeiknek megfelelően lehetővé teszik számukra a következőket: (a) az írástudás, a számtantudás és a digitális kompetenciák minimális szintjének elsajátítása; és/vagy (b) a munkaerőpiac szempontjából releváns, a társadalom életében való aktív részvételt lehetővé tevő, szélesebb körü készségek, tudás és kompetenciák megszerzése, a nemzeti sajátosságoktól függően az EKKR 3. vagy 4. szintű képesítés megszerzése felé haladva, az egész életen át tartó tanuláshoz szükséges kulcskompetenciákról szóló 2006/962/EK ajánlás alapján... A nemzeti sajátosságokat, a rendelkezésre álló erőforrásokat és a már meglévő nemzeti stratégiákat figyelembe véve nemzeti szinten határozzanak meg a kompetenciafejlesztési pályák kínálata szempontjából kiemelt célcsoportokat. Ennek során vegyék figyelembe a célzott népesség nemét, sokféleségét és különböző alcsoportjait... Amennyiben lehetséges, a kompetenciafejlesztési pályák tervezését a következő három lépésre alapozzák: készségfelmérés, személyre szabott, rugalmas és minőségi tanulási ajánlat biztosítása, valamint a megszerzett készségek érvényesitése és elismerése.” A Tanács ajánlása (2016. december 19.) a kompetenciafejlesztési pályákról: Új lehetőségek felnőttek számára (2016/C 484/01). Lásd még erről: A Tanács nyilatkozata a tevé- 
Mindezek az elöirányzott lépések a magyar jogalkotót is cselekvésre indították.

A szakképzés és a felnőttképzés rendszerszintű megújitását célul tűzve dolgozta ki az Innovációs és Technológiai Minisztérium az ún. Szakképzés 4.0 szakmapolitikai stratégiát. ${ }^{9}$

A változások mozgatórugója ebben az összefüggésben a gazdaság folytonosan változó igényeihez igazodik, melynek következtében elsődleges szempont, hogy a szakképzési rendszerből stabil szakmai alapismeretekkel rendelkező, a változásokhoz alkalmazkodni képes egyének kerüljenek a munkaerőpiacra, mindamellett pedig a szakképzési rendszer az egész életen át tartó tanulás lehetőségét is garantálja számukra. Hiszen az iskolapadból kikerülő szakemberek kizárólag a képzés során megszerzett szakmai alaptudás birtokában és a tanulás képességével tudják megfelelően megújítani tudásukat a felnőttképzés és a vállalati továbbképzés rendszerében a szakmai karrierjük során.

A szakmai képzés fejlesztésének három, alapvető pillére a stratégia szerint a vonzó környezet kialakítása a szükséges infrastrukturális fejlesztések biztosításával; a karrier lehetősége a fiatalok és az idősebbek számára egyaránt, mely biztos egzisztenciát és magas jövedelmet nyújt; naprakész tudású oktatók foglalkoztatásával. ${ }^{10}$

A gyakorlati megvalósítás első mérföldkövének tekinthető hazánkban a szakképzési rendszer átalakítását megalapozó, a szakképzésröl szóló 2019. évi LXXX. törvény (a továbbiakban: Szkt.) 2020. január 1-jei hatálybalépése.

A 2020. szeptember 1-jén kezdődő tanévben a szakképzésbe belépő tanulók már az új szabályozás alapján kezdték meg tanulmányaikat. Kiemelendő tehát, hogy a szakképzési rendszer átalakulása csupán azokat a tanulókat érinti, akik 2020 szeptemberétől kezdik meg tanulmányaikat, míg a szakképzési hozzájárulással kapcsolatos rendelkezések csak 2021. január 1-jétöl hatályosak. ${ }^{11}$ Az új jogszabály lényegi változást hozott a választható szakmák tekintetében; 2020. szeptember 1-jétől számuk százhetvennégy választható szakmára csökkent. Az új szakképzési rendszerben a szakmák megszerzése ezt követően is iskolai rendszerü képzésben történik; ötéves technikumokban és hároméves képzési idővel rendelkező szakképző iskolákban.

keny időskor és a nemzedékek közötti szolidaritás európai évéröl: A következő lépések. 2012. december 7.; Flash Barometer 455 on European Youth (2018) (455. sz. Eurobarométer gyorsfelmérés, 2018), a TNS politikai és szociális hálózat által az Európai Bizottság Oktatásügyi, Ifjúságpolitikai, Sportügyi és Kulturális Főigazgatóságának felkérése alapján végzett felmérés. A 15-29 évesek körében a NEET-fiatalok aránya a 2012. évi 15,9\%-os történelmi csúcsról 2017-re 13,4\%-ra csökkent az Eurostat adatai szerint (Sustainable Development in the European Union: Eurostat 2018 Monitoring Report on Progress towards the SDG's in an EU Context - Fenntartható fejlődés az Európai Unióban: az Eurostat 2018. évi ellenőrzési jelentése a fenntartható fejlődési célok teljesítése terén uniós kontextusban elért eredményekről). A Tanács ajánlása (2013. április 22.) ifjúsági garancia létrehozásáról (HL C 120., 2013.4.26., 1. o.). A Tanács ajánlása (2016. december 19.) a kompetenciafejlesztési pályákról: Új lehetőségek felnőttek számára (HL C 484., 2016.12.24., 1. o.). 9 Eurofound (2017), „Long-term Unemployed Youth: Characteristics and Policy Responses” (Tartósan munkanélküli fiatalok: Jellemzők és szakpolitikai válaszlépések), az Európai Unió Kiadóhivatala, Luxembourg.

9 „Szakképzés 4.0 - A szakképzés és felnőttképzés megújításának középtávú szakmapolitikai stratégiája, a szakképzési rendszer válasza a negyedik ipari forradalom kihívásaira”, Innovációs és Technológiai Minisztérium, 2019.

10 Lásd erről bővebben: Szakképzés 4.0 stratégia, 2019, 39.

11 2019. évi LXXX. törvény a szakképzésről (Szkt.) 124. §. 
A technikumi képzés keretében érettségi és technikusi szintű szakképzettség szerezhető, ezzel szemben a szakképző iskolákban folyó képzés befejeztével szakképzettség szerezhető. A technikumban a képzés első két évében, míg a szakképző iskolában az első egy évben széles alapozású ágazati ismeretekre tesznek szert a tanulók, amelyek keretében megszerzett tudásról egy ágazati alapvizsga során adnak számot.

A képzés második ciklusában, a szakképző iskolai képzés során a 9. évfolyam végén, a technikumban a 10. évfolyam végén az ágazaton belül a tanulók szakmát választanak, és az ágazati alapvizsga letételét követően lehetőségük nyílik arra, hogy tanulmányaikat duális képzés keretében folytassák a 10. és a 11. évfolyamon. Ettől kezdve a tanulók szakképzési munkaszerződés keretében vesznek részt a gyakorlati képzésben, melynek eredményeként a képzés alatt jövedelemhez is jutnak. ${ }^{12}$

A technikusi képzés során a négy kötelező közismereti tárgyból tesznek érettségit a diákok a képzés végén, valamint az ötödik érettségi tantárgy esetükben a technikusi szakképesítés szakmai vizsgája lesz. Így a vizsgákat sikeresen abszolváló tanulók a 13. év végén két végzettséget igazoló bizonyítványt is kapnak. Egyrészt kézhez kapják az érettségi bizonyítványt, továbbá a technikusi végzettséget igazoló oklevelet is. A technikumban megszerzett tudás birtokában pedig a jó eredménynyel végzett tanulók a szakmai vizsgájuk eredményének figyelembevételével azonos ágazaton belül folytathatják tanulmányaikat a felsőoktatásban. A végzést követően, a szakképző iskolai képzésben is nyitott a lehetőség az érettségi, vagy akár a technikusi képzettség megszerzésére. Ehhez kapcsolódóan a szakképző iskolát végzettek érettségire felkészítő képzése felnőttoktatás keretében történik annak érdekében, hogy a frissen végzett fiatal szakemberek a végzést követően mihamarabb el tudjanak helyezkedni a munkaerőpiacon, és amellett tanulhassanak esti tanrendben. ${ }^{13}$

Összegzésként elmondható, hogy az új szakképzési struktúra lényege abban rejlik, hogy mindenki számára rugalmas tanulási utakat, nagyobb átjárhatóságot biztosít. A tanulmányaikat gimnáziumban, technikumban vagy szakképző iskolában megkezdők számára is adott a felsőoktatásba történő eljutás lehetősége, illetőleg alapfokú vagy érettségi végzettségre épülő, versenyképes tudást biztosító szakmai képzettséggel léphetnek be a munka világába.

\section{3. Új struktúra - új lehetőségek - új megoldások?}

A negyedik ipari forradalom által támasztott új kihívások kezelésének kulcsa a lehető legszélesebb körü együttmüködésben rejlik.

A megváltozott gazdasági, társadalmi környezethez igazodóan, a közép- és hoszszú távú munkaerőpiaci igényekre alapvetően az iskolai rendszernek kell megfelelő megoldást biztosítania, míg a rövid távú - az új beruházásokhoz, a kapacitásbőví-

\footnotetext{
12 KISSNÉ HoRVÁTH Marianna: Az új szakképzési törvény keretein belüli juttatások adó- és járulékkötelezettsége. In: Pál Lajos-Petrovics Zoltán (szerk.): Visegrád 17.0 A XVII. Magyar Munkajogi Konferencia szerkesztett előadásai. Wolters Kluwer, Budapest, 2020, 245-246.

${ }^{13}$ Lásd erről bővebben: Szakképzés 4.0 stratégia, 2019, 40-41.
} 
téshez, modernizáláshoz kapcsolódó - elvárások tekintetében a megfelelő színvonalú felnőttképzés jelentheti a megoldást. ${ }^{14} \mathrm{~A}$ napjainkban végbemenő rohamos technológiai fejlődés eredményeképpen kulcsfontosságúnak bizonyul, hogy a munkavállalók megfelelő adaptációs képességek birtokában jelenjenek meg a munkaeröpiacon és képesek legyenek a megszerzett tudás folyamatos fejlesztésére, gyarapítására, melynek köszönhetően versenyképes szereplői lehetnek a munka világának. Mindez pedig a munkáltatók szempontjából is kiemelt jelentőséggel bír, tekintettel arra, hogy a megfelelően képzett és megújulni képes munkavállalók alkalmazásával hatékonyan csökkenthető az adott szervezeten belül a fluktuáció, hozzájárulva mindezzel a hatékonyabb munkavégzéshez és a versenyképesség növeléséhez a munkáltató szintjén egyaránt. ${ }^{15}$

Eddigi megállapításaink fényében körvonalazódik, hogy az új struktúra a szakképzés és a felnőttképzés rendszerében új lehetőségeket és új megoldásokat is tartogat. Lehetőséget teremt egyrészt arra, hogy a szakképzés rendszere biztos tudáson alapuló szakmai ismereteket és egyben rugalmasságot is biztosítson, amelyek megalapozzák, hogy a képzésben részt vevők felvértezzék magukat a munkaeröpiacon elengedhetetlen kulcskompetenciákkal, valamint arra, hogy kialakuljon az élethosszig tartó tanulásra való igény és képesség. Továbbá, lehetőséget nyújt arra is, hogy a felnőttképzés keretében a már előzetesen megszerzett ismeretek beszámításával a speciális szakmai ismeretek, valamint az innovatív technológiákhoz nélkülözhetetlen tudás elsajátítható legyen.

Annak érdekében, hogy a piaci igényekhez történő alkalmazkodás a lehető leghatékonyabb módon valósuljon meg, jelentős változtatások történtek a szakmai képesítések megszerzésének területén. A rugalmasság biztosítását szem előtt tartva ugyanis nincs jogszabályban rögzítve a szakmai képzés ${ }^{16}$ keretében megszerezhető szakképesítések köre. A programkövetelmények tartalmazzák egyrészről az adott programkövetelmény alapján szervezhető szakmai képzés tartalmi (kimeneti) követelményeit, másrészt pedig a szakmai képzéshez kapcsolódó - a szakmai képzéstől

${ }^{14}$ Lásd erről bővebben: Szakképzés 4.0 stratégia, 2019, 46.

${ }^{15}$ A megváltozott munkaszervezési formák, az új technológiai és tudományos eredmények a XXI. században alapvetően a bizonytalanság és aggodalom érzését keltik a munkavégzőkben. A munkaerőpiac a versenyszféra ringje, ahol a munkavégzök is meglehetösen nagy önbizalommal és komoly szakmai tudással tudnak csak érvényesülni. Ez a környezet megnehezíti és kihívások elé állítja a munkaerőpiac, az oktatási rendszer, a rehabilitáció, azon belül a foglalkozási rehabilitáció intézményét. Hiszen, aki ma boldogulni szeretne a nyílt munkaeröpiacon az alábbi tulajdonságokkal kell rendelkezzen: fejlett interperszonális képességek, csapatmunkára való képesség, problémameghatározó és -megoldási képesség, folyamatos tanulásra és megújulásra való képesség, az új technológiák befogadására való képesség.

A munkához való állandó alkalmazkodás a sikeres foglalkoztatás kulcsa lett. A fenti tulajdonságok mind ezt a rugalmasságot segítik elő. A munkavégzőket a karrier-szemlélet még erősebben érinti a XXI. században. MurRAY, Barbara-Heron, Robert: Placement Of Job-Seekers With Disabilities. Elements of an Effective Service. International Labour Organisation, 2003, 3-4.; HoLmES, Jain: Vocational Rehabilitation. Blackwell Publishing, Oxford, 2007, 7-9.

${ }^{16}$ Szakmai képzés a megszerezhető szakképesités kimeneti követelményeit tartalmazó, a szakképzésért felelős miniszter által nyilvántartásba vett programkövetelmény alapján indítható. Programkövetelményre, annak módosítására és törlésére pedig bárki javaslatot tehet a szakképzésért felelős miniszter felé. Lásd erröl: A szakképzésről szóló törvény végrehajtásáról szóló 12/2020. (II. 7.) Korm. rendelet (a továbbiakban: Szkr.) 17-20. §. 
elváló és függetlenül szervezett - képesítő vizsga megszervezéséhez szükséges feltételek és a képesítő vizsga vizsgatevékenységeinek részletes leírását. Felnőttképzés keretei között pedig ehhez kapcsolódóan egyrészt a részszakmára felkészítő szakmai oktatás és szakképesítésre felkészítő szakmai képzés folytatható. ${ }^{17}$

Az új struktúra kialakításakor alapvető célkitúzésként jelent meg, hogy az eddig elérhető, rendkívül széles körü országos képesítési rendszer - Országos Képzési Jegyzék (a továbbiakban: OKJ) - esetében szükséges a képzések racionalizálása, átláthatóbbá tétele, igazodva a foglalkoztatók és a munkaerőpiac igényeihez és a modernizációs törekvésekhez. A megváltozott rendszer szakított az eredeti, OKJstruktúrával. A szakképzési törvény végrehajtási rendeletében megjelent Szakmajegyzék tartalmazza a jelenleg megszerezhető szakképesítések körét. ${ }^{18}$ Mindez 25 ágazathoz kapcsolódóan 175 szakmát ölel fel, mely lényegesen kevesebb az előző rendszerben meghatározottakhoz képest. ${ }^{19} \mathrm{~A}$ rendszer átstrukturálásában kulcsfontosságú volt, hogy mindez valóban a gazdaság igényeihez igazodó alapvetések mentén történjen, így a piaci igényekhez rugalmasan igazodó képzési struktúra meghatározásában kulcsfontosságú tényezőként jelentek meg az ún. Ágazati Készségtanácsok (a továbbiakban: ÁKT). ${ }^{20}$ Fontos szempont volt továbbá, hogy az egyes ágazatokhoz igazodóan a digitális kompetenciák fejlesztése is megvalósuljon. ${ }^{21}$

\section{Megoldások és következtetések a raktározási ágazatot érintően}

Az eddigi vizsgálódás fényében betekintést nyerhettünk a napjainkban hatályos képzési struktúra alakulásába. A téma szempontjából pedig elengedhetetlen ezen a ponton a raktározási ágazathoz kapcsolódóan behatóbban foglalkozni a targonca-, illetve rakodógép-vezetői engedély megszerzéséhez kapcsolódó képzettség megszerzésének kérdéskörével.

Hazánkban eddig alapvetően három tényező együttes fennállása volt szükséges ilyen tevékenység végzéséhez: targonca-, illetve rakodógép-vezetői engedély, megfelelő OKJ-s vizsga, valamint az adott telephelyre szóló megbízás. Tekintettel arra, hogy a raktározási ágazat esetében kihívást jelent a munkaerőhiány, érdemes szólni a foglalkoztatáshoz szükséges képesítés megszerzésének lehetőségéről. Hiszen úgy tủnhet, hogy amennyiben a megfelelő képesítés hiányában - esetleg adott

\footnotetext{
17 Ennek lehetőségeiről lásd: A felnőttképzésről szóló 2013. évi LXXVII. törvényt (a továbbiakban: Fktv.).

18 „A kizárólag szakképző intézményben szakmai oktatás keretében elsajátítható szakmákat a Kormány rendeletben állapitja meg (a továbbiakban: szakmajegyzék). A szakmajegyzékben szakmánként meg kell határozni a szakma azonosító számát, ennek keretében tanulmányi területét, ágazati besorolását, szintjének meghatározására vonatkozó megjelölését, a szakma megnevezését, a hozzá kapcsolódó szakmairányt, a szakmai oktatás időtartamát és a 107. § (2) bekezdése szerinti súlyszorzót." Szktv. 10. §. A szakmajegyzéket lásd a 12/2020. (II. 7.) Korm. rendelet 1. sz. mellékletében.

19 12/2020. (II. 7.) Korm. rendelet 1. sz. melléklet.

20 „Az Ágazati Készségtanácsok feladata, hogy elösegítsék a munkaerö-piaci igények és a képzési rendszer összhangjának megteremtését, valamint véleményezési, illetve javaslattételi munkával hozzájáruljanak a szakképzési és felnőttképzési rendszer müködtetéséhez, szükséges átalakitásának folyamatához." Szakképzés 4.0 stratégia, 2019, 47.

21 Szakképzés 4.0 stratégia, 2019, 49.
} 
gyakorlati időtartam - is elvégezhető lehetne ezen tevékenység, mindez hatékony megoldást jelenthet az ágazatot terhelő munkaerőhiány kapcsán, mivel jóval egyszerübben lehetne elhelyezkedni ezekben a munkakörökben. Rövid távon valóban ígéretesnek tủnhet ez a megoldás, mivel feltehetőleg jóval szélesebb munkavállalói kör számára állna nyitva az adott pozíció, ám hosszabb távon mindez rendkívül kockázatos helyzetet teremtene a munkáltatók számára. Vitán felül áll, hogy a megfelelő munkatapasztalat valamennyi esetben plusz tényezőként értékelhető, ám véleményünk szerint, a targonca-, illetve rakodógép-vezetői munkakörök ellátása esetében mindez - a vezetöi engedély meglétével - nem lehet elegendő az adott feladat ellátásához. A munkavállalók képzésének ezen a területen szervezett keretek között, a korábbi OKJ-rendszernek megfelelö, szakmai képzés keretében kell történnie. Ennek relevanciája megmutatkozik abban, hogy ennek köszönhetően az egységes képzés valamennyi munkavállalónak azonos szintű tudást és egyenlőbb feltételeket biztosítana az ország minden pontján az elhelyezkedés során. Mindez az Európai Unió által meghatározott célkitüzésekhez is megfelelöen illeszkedne. Egy megfelelően szervezett, versenyképes tudást biztosító képzés pedig nagyobb tömegek megszólítására is alkalmas lehet, melynek következtében a jelenleg munkanélküli réteg raktározási ágazatban történő elhelyezkedése is nagyobb eséllyel megvalósulhat, így ennek tágabb kontextusban az állami ellátórendszer is előnyét élvezhetné. A foglalkoztatók szempontjából pedig kimondottan fontos, hogy a raktározás területén megfelelő számban álljanak rendelkezésre a megfelelő képesítésü munkavállalók. Tekintettel arra, hogy a targonca-, illetve rakodógép-vezetői munkakörök esetében kiemelten fontos, hogy a munkavállalók biztonsággal és kellő szakértelemmel kezeljék a munkavégzés során a gépeket annak érdekében, hogy megóvják az esetleges károkozástól a munkáltatót, valamint saját magukat is. Az áruk, anyagok stb. megfelelő mozgatásával, kezelésével alapvetően csökkenthetik a foglalkozási megbetegedések bekövetkezésének eseteit, mely plusz költségek megfizetésétől mentesíti a munkáltatót. Mindez pedig megalapozza, hogy a munkáltató a gazdaság versenyképes szereplője legyen a múködése során, pozitív hatást gyakorolva ennek következtében a piaci verseny alakulására is.

Mindezek tükrében úgy véljük, hogy egy ilyen, fokozottan veszélyes területhez kapcsolódóan a szakmai tapasztalat - a vezetői engedély megszerzése mellett nem lehet elegendő a munkakör betöltéséhez, a megfelelö, stabil szakmai tudást biztosító képzettség megszerzése kulcsfontosságú az eredményes és biztonságos foglalkoztatáshoz.

\section{Az egészséges munkakörnyezet}

Az egészséges munkakörnyezethez való jogosultság biztosítása kiemelt relevanciával bír valamennyi, foglalkoztatásra irányuló jogviszony vonatkozásában. Kulcsfontosságú követelményként jelenik meg a jogviszonyban, tekintettel arra, hogy a megfelelő, egészséget nem veszélyeztető, biztonságos munkakörnyezet kialakítása és fenntartása jelentős mértékben meghatározhatja, hogy miként és meddig képes a jogviszony megfelelően betölteni rendeltetését. Hiszen a megfelelő munka- 
feltételek biztosítása a munkavállalók számára nélkülözhetetlen annak érdekében, hogy egészségüket megőrizve, a lehető legteljesebb mértékben képesek legyenek feladataik ellátására, mindezzel hozzájárulva a munkáltatói szervezet gazdasági versenyképességének, termelékenységének fenntartásához. Ezen kontextusra tekintettel talán nem túlzás azt állítani, hogy a munkahelyi biztonság és egészség tárgyköre nemzetgazdasági jelentőségú területként értékelhető, amely megköveteli a megfelelő mértékủ aktív állami szerepvállalást a szabályozás kapcsán, meghatározva ezáltal a kereteket, illetöleg az ezek tartalmát biztostó részletszabályok körét. Ennek kapcsán nem elhanyagolható, hogy a nemzeti szintủ jogalkotási aktusok mellett az 1980-as évek óta egyre növekvő uniós szabályozási fellépést láthatunk a munkahelyi egészségvédelem és biztonság javítását célozva. ${ }^{22}$

A negyedik ipari forradalom kihívásai jelentősen érintik a munkavédelem tárgykörét is, mely fokozott és tudatos fellépést követel az állami szerepvállaláson túl a munkáltatók részéről egyaránt. $A$ téma jelentőségéhez mérten szükségesnek véljük néhány gondolat erejéig az alapjogi vetületek ismertetését a következőkben.

\section{A munkavédelem alapjogi vetületei}

A munkavállalói jogok körében hazánkban az Alaptörvény deklarálja, hogy minden munkavállalónak joga van az egészségét, biztonságát és méltóságát tiszteletben tartó munkafeltételekhez, valamint a testi-lelki feltöltődéshez a napi és heti pihenőidőhöz, továbbá az éves fizetett szabadsághoz. ${ }^{23}$ Kiemelést érdemel, hogy az Alaptörvény a munkavállaló fogalmát egy olyan általános fogalomnak tekinti, mely a foglalkoztatottak teljes körére kiterjed, melynek értelmében a rendelkezéseit valamennyi foglalkoztatásra irányuló jogviszony tekintetében tiszteletben kell tartani. ${ }^{24}$ Rögzíti továbbá az Alaptörvény, hogy a munkaadói és munkavállalói oldalt kölcsönösen együttmüködési kötelezettség terheli, ${ }^{25}$ mely a felek közötti partneri együttmüködés kereteinek kialakítását hivatott biztosítani. Ezen irányvonal mentén az Alaptörvény által biztosított kereteket tartalommal megtöltő jogalkotási feladat ugyancsak az államot terheli. Az alkotmányos rendelkezések vizsgálatából mindezek fényében látható, hogy az Alaptörvény szabályai ténylegesen mindkét fél egyenlő mértékủ védelmét kívánják garantálni, ebböl adódóan pedig az Alaptörvény rendelkezéseivel összhangban lévő speciális részletszabályok megalkotása kiemelt jelentőséggel bír.

A munkavállaló és a munkáltató közti partneri együttmüködés célját az alkotmányos szabályok is megállapítják, mintegy program jellegüen: ide tartozik a munkahelyek biztosítása, a nemzetgazdaság fenntarthatósága és más közösségi célok. ${ }^{26}$ Mindezek hatékony biztosításához pedig elengedhetetlen követelmény a munkakörülmények megfelelő kialakítása, a munkavállalók egészségének, biztonságának védelme.

\footnotetext{
${ }^{22}$ Munkahelyi egészségvédelem és biztonság: Az Európai Unió ismertetése, 2019, 1. http://www.europarl.europa.eu /ftu/pdf/hu/FTU_2.3.5.pdf (2021.07.01.).

${ }^{23}$ Magyarország Allaptörvénye (2011. április 25.), XVII. cikk (3)-(4).

24 JакAв Nóra: Munkavédelem - különös tekintettel a felelösségi kérdésekre. Bíbor, Miskolc, $2016,11$.

${ }^{25}$ Magyarország Alaptörvénye (2011. április 25.), XVII. cikk (1)-(2).

${ }^{26}$ Magyarország Alaptörvénye (2011. április 25.), XVII. cikk (1).
} 
A munkafeltételekkel kapcsolatos szabályok az eddigi vizsgálódásunk fényében egyértelmüen a munkavállalók érdekeit szolgálják, melynek részletszabályait a Munka Törvénykönyvéröl szóló 2012. évi l. törvény (továbbiakban: Mt.) tartalmazza. Ám ezen túl, az állam munkavédelmi tárgyú jogszabályok széles körével biztosítja a munkavállalók egészségének és biztonságának megőrzését. Ide tartozik többek között a munkavédelem általános szabályrendszerét lefektető Munkavédelemről szóló 1993. évi XCIII. törvény (továbbiakban: Mvt.). ${ }^{27}$

A közösségi szintủ szabályozást tekintve egyaránt számos jogalkotási eredményt találunk a munkavédelem területét érintően. Az uniós szintű jogszabályok bevezetésével meghatározták azon minimumkövetelményeket, melyek a munkavállalókat megillető védelem megfelelő szintjét biztosítják, egyúttal lehetővé téve az ettől szigorúbb intézkedések fenntartását, illetőleg bevezetését. A Lisszaboni Szerződés hatálybalépésével az Európai Unió Alapjogi Chartája jogilag kötelező erejü lett az uniós intézmények és tagállamok számára az uniós jog végrehajtásakor, mely jelentős mértékben hozzájárult ahhoz, hogy az egészségvédelmi és biztonsági politika az uniós jogalkotás még fontosabb területévé vált. Ehhez kapcsolódóan nélkülözhetetlen említést tenni a 89/391/EGK keretirányelvröl, mely mérföldkövet jelentett a munkavállalók biztonságának és egészségvédelmének fejlődését tekintve. Legalapvetőbb célja a munkavállalók munkahelyi biztonságának és egészségének javítását ösztönző intézkedések bevezetése. ${ }^{28}$ Ennek megvalósításában a legmegfelelöbb megoldásként a megelőzés kultúrájának megteremtését véli a közösségi jogalkotó. Kiemelt hangsúlyt fektetett a megelőző intézkedések biztosítására, továbbá tájékoztatást, konzultációt, kiegyensúlyozott részvételt és képzést határoz meg a munkavállalók és képviselőik számára, az állami és magánszektorban egyaránt. ${ }^{29}$

Jelentősége továbbá abban is megmutatkozik, hogy alapul szolgált több mint huszonöt egyedi irányelv megszületéséhez a munkavédelem területét érintően, valamint az Európai Munkahelyi Biztonsági és Egészségvédelmi Ügynökség (EUOSHA) létrehozásáról szóló 2062/94/EK tanácsi rendelethez. Az Ügynökség székhelye Bilbaóban található, 1996-ban jött létre, tevékenysége igen sokrétü, legföbb célkitűzése az ismeretek és információk megosztásának előmozdítása, valamint a prevenció jegyében a kockázatmegelőzés kultúrájának terjesztése. Közel húsz esztendeje rendez minden évben figyelemfelkeltő kampányokat „Egészséges munkahelyek" címmel különböző témákban a munkahelyi egészségvédelemmel és biztonsággal kapcsolatban. 2014 júniusában a Bizottság közzétette az Európai Unió 2014-2020-as munkahelyi biztonsági és egészségvédelmi stratégiai keretét, melyet a Tanács 2015 májusában elfogadott. A keret célkitüzései között három jelentős kihívás kezelése szerepel: a meglévő szabályok egyszerüsítése, korrigálása; a munkavégzéssel összefüggő megbetegedések megelőzésének fokozása; és a munkaerő elöregedésének figyelembevétele.

\footnotetext{
${ }^{27}$ A munkavédelem témakörét érintően lásd: SIPKA Péter: A munkáltatói kárfelelősség alakulása a bírói gyakorlat tükrében. HVG-ORAC, Budapest, 2015.

28 JAKAB: i. m., 27-28.

${ }^{29}$ Munkahelyi egészségvédelem és biztonság: Az Európai Unió ismertetése, 2019, 1-3. http://www.europarl. europa.eu/ftu/pdf/hu/FTU_2.3.5.pdf (2021. 07. 01.).
} 
Az uniós jogalkotás eredményeit tekintve, megkerülhetetlennek véljük az Európai Parlament szerepének ismertetését a munkavédelem tárgykörét érintően. Többek között számos állásfoglalást fogadott el, melyekben azt szorgalmazta, hogy a munkavállalók fizikai, illetőleg szellemi jólétét közvetlenül vagy közvetve befolyásoló valamennyi szempontra vonatkozzon uniós jogszabály. Ehhez kapcsolódóan arra ösztönözte a Bizottságot, hogy vizsgálja meg a hatályos jogszabályok által még nem szabályozott, újonnan felmerülő kockázatokat, mint például a munkahelyi stresszt és a kiégést.

Továbbá rendkívül előretekintő módon igyekszik feltérképezni a technológiai innovációval, s annak a munkaszervezésre gyakorolt hatásával kapcsolatosan felmerülő új kockázatokat, a digitalizáció, a robotika és a mesterséges intelligencia munkaerőpiacra gyakorolt hatásaival foglalkozó munkacsoport révén, melyet a Foglalkoztatási és Szociális Bizottság hozott létre..$^{30}$

\section{Kockázatok}

Valamennyi munkát végző személy - az ellátott tevékenység milyenségétől függetlenül - a fizikai megterhelésen túl, folyamatos mentális és pszichés megterhelésnek van kitéve a munkavégzés során. Mindez abból fakad, hogy a munkavállaló környezetével állandó kölcsönhatásban van, szervezetének megterhelése pedig a munkakörnyezet és a társadalmi környezet között fellépő kölcsönhatásokra vezethető vissza. Ezen tényezők együttesen fejtik ki hatásukat, s komplex módon befolyásolják a munkavállalók egészségét, munkavégző képességét, jóllétét, végső soron az életminőségüket. ${ }^{31}$

A munkavállaló életében a pszichoszociális kockázatok egyik leggyakoribb megjelenési formája a munkahelyi stressz, mely az európai munkavállalók közel felét érinti, véleményük szerint az elvesztegetett munkanapok is a stressz rovására írhatók. Ide sorolható továbbá a kiégés-tünetegyüttes (burnout-szindróma), valamint a munkahelyi pszichoterror is. Viszonylag hosszabb ideig képes lehet a munkavállaló megbirkózni a túlzott munkahelyi megterhelésből eredő következményekkel, ám mindez eljuthat arra a pontra, amely után az egyén már nem képes ellensúlyozni a negatív hatásokat, mely pszichoszomatikus betegségek sokaságát válthatja ki, s hibázások, tévesztések, munkabalesetek oka is lehet. Az ilyen pszichoszociális kóroki tényezőkre visszavezethető megbetegedések pedig adott esetben akár baleseti ellátásra is jogosító foglalkozási megbetegedésnek is minősülhetnek. ${ }^{32}$

\footnotetext{
${ }^{30}$ A munkaviszonyok átalakulásáról és az ennek nyomán fellépő szabályozási kockázatokról lásd: KuN Attila: Munkajogviszony és a digitalizáció - rendszerszintű kihívások és kezdetleges Európai Uniós reakciók. In: Pál Lajos-Petrovics Zoltán (szerk.): Visegrád 15.0. AXV. Magyar Munkajogi Konferencia szerkesztett előadásai. Wolters Kluwer Hungary Kft., Budapest, 2018, 413-415.

31 Lásd Pszichoszociális kockázatok és a munkahelyi stressz. https://osha.europa.eu/hu/themes/psychosocialrisks-and-stress (2021. 07. 01.).

32 A munkahelyi pszichoszociális kockázatok kezelése. https://www.nincsbaleset.hu/dokumentumok/23-a-munkahelyipszichoszocialis-kockazatok-kezelese (2021. 07. 01.).
} 
Mindezek tudatában, az adott gazdálkodó szervezet részéről kulcsfontosságú lehet a megfelelő kockázatértékelés, a prevenció előtérbe helyezése, hiszen a munkavállaló ilyen jellegủ megbetegedései a szervezet egészére kiterjedően éreztetik hatásukat, mely megnövekedett kártérítési igények és egészségügyi jellegü kiadások növekvő számával járhat.

A raktározási ágazatban különösen fontos a munkakör betöltésével járó fokozott fizikai, valamint pszichikai megterhelés figyelembevétele, erre tekintettel kétséget kizáróan kijelenthetjük, hogy a munkavédelem kiemelt relevanciával bír ebben az ágazatban. Amennyiben a munkavállalót a munkája ellátása során baleset éri, a munkáltató kártérítési felelőssége merül fel. A Munka Törvénykönyve rendelkezései szerint:

166. § (1) A munkáltató köteles megtéríteni a munkavállalónak a munkaviszonynyal összefüggésben okozott kárt. ${ }^{33}$

(2) Mentesül a felelósség alól, ha bizonyítja, hogy

a) a kárt az ellenörzési körén kívül eső olyan körülmény okozta, amellyel nem kellett számolnia, és nem volt elvárható, hogy a károkozó körülmény bekövetkezését elkerülje, vagy a kárt elhárítsa, vagy

b) a kárt kizárólag a károsult elháríthatatlan magatartása okozta. ${ }^{34}$

Az Mt. a munkáltatói kártérítési felelösség körében megtartja a munkáltatói kárfelelösség jogalapjára vonatkozó általános szabályt, az ún. objektív (vétkességtöl független) kárfelelősséget. Ennek a rendelkezésnek, illetve a polgári jog szabályainak alkalmazására tekintettel levezethető, hogy a munkavállaló köteles bizonyítani a károkozásnak a munkaviszonnyal fennálló okozati összefüggését, ugyanígy a keletkezett kárt, illetve annak összegét is. A törvény az általános objektív felelösség vonatkozásában a munkáltató számára új kimentési okot nevesít, amikor a működési kör fogalmát felváltja az ellenőrzési kör fogalmával. A jogalkotó szándéka ezzel egyértelműen a munkáltatói kártérítési felelősség szélesebb körének szűkítését célozta, törekedve arra, hogy a polgári jog veszélyes üzemi felelőssége a munkáltatói kárfelelősség körében általános érvényü legyen. ${ }^{35}$

A raktározási ágazatban, a targonca, illetve rakodógép vezetése a tevékenység fokozottan veszélyes jellegére tekintettel speciális felelősségi alakzat, a veszélyes üzemi felelősség merül fel. ${ }^{36}$

A Polgári Törvénykönyv (a továbbiakban: Ptk.) rendelkezései szerint, aki fokozott veszéllyel járó tevékenységet folytat, köteles az ebből eredő kárt megtéríteni. Mentesül azonban a felelősség alól, ha bizonyítja, hogy a kárt olyan elháríthatatlan ok idézte elő, amely a fokozott veszéllyel járó tevékenység körén kívül esik. ${ }^{37}$ Kiemelten

${ }^{33}$ Kúria Mv.l.10.362/2015/7.

${ }^{34}$ Kúria Mv.l.10.362/2015/7.

${ }^{35}$ JAKAB: i. m., 98-100.

${ }^{36}$ „Fokozott veszéllyel jár azon tevékenység, amelynek a gyakorlása során fellépö, viszonylagosan csekély mértékü rendellenesség is súlyos kárral fenyegető veszélyhelyzetet teremthet. Fokozottan veszélyesnek tekinthető a tevékenység abban az esetben is, ha a tevékenység folytatójának csekélyebb mértékü vétkessége súlyos kárveszély bekövetkezésével fenyegetö helyzetet teremthet, továbbá, ha egyszerre nagyobb számú személy életét, testi épségét, egészségét vagy vagyonát fenyegető kárveszélyt idéz elö." BDT2012. 2661.

${ }^{37}$ Ptk. 6:535. § (1) bek. 
fontos ennek körében azon személy meghatározása, akinek érdekében az adott tevékenységet folytatják, mivel őt kell a továbbiakban üzembentartónak tekinteni. ${ }^{38}$ Mindezek fényében pedig kiemelten fontosnak bizonyul, hogy a tevékenység ellátásához kapcsolódóan a munkáltató valamennyi munkavédelmi előírásnak eleget tegyen a munka megszervezése, ellenőrzése során is, hiszen ennek köszönhetően jelentős kártérítési összegek megtérítésétől óvhatja meg magát. A munkakör megfelelő szintű ellátása pedig többek között a tevékenység fokozottan veszélyes jellegére tekintettel biztos és alapos szakmai tudást igényel a munkavállalók részéröl, a szakmai gyakorlat megléte nem mentesítheti a szakképesítés megszerzésétől.

38 „A fokozott veszéllyel járó tevékenység folytatójának az minősül, akinek érdekében a veszélyes üzem müködik.” 